\title{
Effects of starvation on aggregate colonization and motility of marine bacteria
}

\author{
Emily M. Yam ${ }^{1, *}$, Kam W. Tang ${ }^{1}$ \\ ${ }^{1}$ Virginia Institute of Marine Science, 1208 Greate Road, Gloucester Point, Virginia 23062, USA
}

\begin{abstract}
Fluxes of particulate matter to depth and dynamics of dissolved organic matter in the water column are influenced by microbial processes associated with organic aggregates like marine snow. These microscale processes include the encounter between bacteria and aggregates, which has been previously modeled and tested with well-fed and actively growing bacteria. In the present study, we investigated the effects of starvation on initial bacterial colonization of aggregates by measuring colonization and detachment of 6 isolates in different physiological states (fed vs. starved) using model aggregates. Because aggregate encounter depends on motility, the motility behaviors of fed and starved bacteria of 3 selected strains were also compared using image analysis. All 6 fed isolates colonized faster and achieved significantly higher steady-state abundances on model aggregates than those that were starved. However, there was no difference in detachment rates between fed and starved bacteria. The 3 selected strains had significantly lower average swimming speeds when starved. Diffusivities calculated from motilities of 2 starved isolates were more than 6 times lower than those of their fed counterparts. Our results show that starvation significantly affects bacterial behavior and bacteria-aggregate interactions, which may lead to differences in particulate and dissolved organic matter fluxes and cycling under different productivity regimes.
\end{abstract}

KEY WORDS: Bacterial colonization - Detachment - Motility - Image analyses · Aggregates · Starvation Resale or republication not permitted without written consent of the publisher

\section{INTRODUCTION}

Marine aggregates constitute up to $63 \%$ of the total particulate organic carbon in some parts of the ocean (Alldredge 1979), and could be important for carbon sequestration even in oligotrophic waters (BenitezNelson et al. 2001, Pilskaln et al. 2005). Marine aggregates are often sites of elevated heterotrophic activity (Silver et al. 1978, Caron et al. 1982, Alldredge \& Gottschalk 1990, Artolozaga et al. 1997, Dilling et al. 1998), and colonization and subsequent solubilization of aggregates by bacteria can influence biogeochemical cycling of organic matter (Cho \& Azam 1988, Smith et al. 1992). Aggregate-associated bacteria typically comprise a small portion of the total bacteria in the water column (Kirchman 1993, and references therein). However, per unit volume, aggregates are highly enriched with bacteria relative to the ambient water (Simon et al. 2002). Three functional types of bacteria have been described based on their interactions with aggregates (Grossart et al. 2006): (1) freeliving bacteria that tend not to attach to aggregates, (2) 'particle-specialists' that specialize in colonizing particles and aggregates, and (3) 'generalists' that can grow both in suspension and on particles. Particlespecialists are phylogenetically distinct from the others (DeLong et al. 1993, Grossart et al. 2006), and their survival may depend on their ability to locate and colonize aggregates.

Short-term colonization of aggregates by bacteria, occurring on a scale of minutes to a few hours, is governed by the rate at which bacteria encounter, attach to, and detach from the aggregates (Kiørboe et al. 2002). In still water, encounter rate depends on the aggregate size, ambient concentration of bacteria, and diffusivity of the bacteria, which is in turn determined by motility of the bacteria. Bacterial motility can be described as 'random walk' where straight runs are 
interrupted by tumbles when the bacteria randomly reorient their swimming direction (Berg 1983). Differences in bacterial diffusivity can be partly attributed to differences in run speeds, run duration, turn angles and turn frequency (Mitchell \& Kogure 2006). Bacteria may also change their motility patterns in response to chemical stimuli (Mitchell 1991, Fenchel 2001, Thar \& Kuhl 2003) or physiological stress (Malmcrona-Friberg et al. 1990, Wrangstadh et al. 1990, Stretton et al. 1997, Wei \& Bauer 1998), and these responses can be heterogeneous even within a population (Stretton et al. 1997). A study by Wrangstadh et al. (1990) suggests that both adhesion and detachment of Pseudomonas sp. from surfaces could be affected by starvation in as little as $3 \mathrm{~h}$. After the onset of starvation, peripheral exopolymer substance (EPS) production prevented flagellar movement in bacteria by increasing the viscosity around the cell (Wrangstadh et al. 1990). MalmcronaFriberg et al. (1990) showed that the portion of motile cells decreased from $60 \%$ to nearly zero after 3 to $24 \mathrm{~h}$ of starvation due to the loss of flagella. Wei \& Bauer (1998) reported that prolonged starvation in the terrestrial bacterium Rhizobium meliloti resulted in a graded response, ranging from loss or modification of flagella to inactivation of the flagellar motor.

Kiørboe et al. (2002) estimated that the search time for a bacterium to encounter an aggregate in the upper ocean was 0.02 to $12 \mathrm{~d}$, with a median of $0.4 \mathrm{~d}$; thus, most bacteria should reach an aggregate within $1 \mathrm{~d}$ of continuous searching. However, this estimation assumes constant diffusivity and velocity for well-fed, exponentially growing bacteria (Kiørboe et al. 2002). Because bacteria may change motility or physiology within only a few hours of starvation, previous estimates of search time, encounter, and colonization rates may not apply to situations where bacteria may starve between successful encounters with aggregates, especially in nutrient-limiting environments.

The goal of this study was to investigate the effects of starvation on short-term bacterial colonization of aggregates and motility patterns. First, we compared the colonization and detachment rates of 6 strains of marine bacteria under fed vs. starved conditions using model aggregates (agar beads). To further describe the effects of starvation on colonization rates, we selected 3 of the bacterial strains and studied their motility patterns under different nutritional conditions.

\section{MATERIALS AND METHODS}

Bacterial isolates. Bacterial strains HP1, HP5, HP11, HP66 were originally isolated from aggregates in the Wadden Sea, Germany (Grossart et al. 2004). The strains have been identified as Curacaobacter baltica
(HP1; GenBank Accession No. AJ002006), Frigobacterium sp. strain GOB (HP5; AF321022), Microscilla furvescens (HP11; M58792) and Marinobacter sp. strain NCE312 (HP66; DQ148445) (H.-P. Grossart pers. comm.). Cultures of the isolates were maintained on solid media (2\% marine broth agar). Additional strains (YR3, YR7) were isolated from the York River, Virginia, USA, on solid media. Fed and starved bacteria were prepared by resuspending isolates in liquid media for $24 \mathrm{~h}$ at $22^{\circ} \mathrm{C}$ in the dark: for the fed treatment, bacteria were inoculated in $1 \%$ marine broth $(\mathrm{MB})$; for the starved treatment, bacteria were inoculated in organic matter free, nutrient-free water (NFW) prepared according to Caron (1993).

Bacterial colonization and detachment. We used model aggregates made of $2 \%$ agar (Fisherbrand) in artificial seawater according to Cronenberg (1994). The use of agar beads as an analog to marine aggregates is a proven and effective means for studying initial microbial colonization of aggregates (Kiørboe et al. 2002, 2003). Fed or starved bacteria were resuspended into experimental chambers with $500 \mathrm{ml}$ of NFW at a concentration of $10^{5}$ cells $\mathrm{ml}^{-1}$. Negligible levels of $\mathrm{MB}$ from the fed treatment were introduced into the experimental chambers $(<0.4 \%$ of the final experimental volume). As such, observed differences between fed and starved bacteria could be attributed to the different physiological status of the bacteria rather than differences in the ambient environments.

For the colonization experiments, agar beads (4 mm in diameter) were suspended by glass needles in the experimental chambers for up to $150 \mathrm{~min}$. At each sampling point, triplicate beads were removed and bacteria attached to the bead surfaces were enumerated using DAPI direct counts at $600 \times$ magnification. A $1 \mathrm{ml}$ aliquot of the ambient bacteria was also counted at the start and end of the colonization experiment. The model of Kiørboe et al. (2002) was fitted to the data to estimate diffusivities $\left(D_{\mathrm{m}}\right)$ and detachment rates $\left(\delta_{\mathrm{m}}\right)$ :

$N_{t}=4 \pi a C D_{\mathrm{m}}\left\{1+\exp \left(-\delta_{\mathrm{m}} t\right) \cdot\left(\operatorname{erfi}\left[\left(\frac{D_{\mathrm{m}} t}{a^{2}}\right)^{0.5}\right]\left(\frac{a^{2} \delta_{\mathrm{m}}}{D_{\mathrm{m}}}\right)^{0.5}-1\right)\right\} / \delta_{\mathrm{m}}$

where $N_{t}$ is bacterial abundance on agar beads; $a$ is radius of agar beads; $C$ is ambient bacterial concentration; $t$ is time; erfi is the imaginary error function for integrating a Gaussian distribution. $D_{\mathrm{m}}$ determines the rate at which the bacteria encounter an aggregate based on random-walk motility, whereas $\delta_{\mathrm{m}}$ determines the rate at which recently attached bacteria detach from the aggregate. Because $D_{\mathrm{m}}$ and $\delta_{\mathrm{m}}$ are not independent of each other in the model, we further define a colonization coefficient $\left(R_{\mathrm{m}}\right)$ as the numerical value of $D_{\mathrm{m}} / \delta_{\mathrm{m}}$, which characterizes the net accumula- 
tion of bacteria on the aggregate, and allows us to compare the colonization rates between treatments.

At the end of the colonization experiments, remaining beads with attached bacteria were transferred to NFW, and the detachment of bacteria from the agar beads was monitored over a course of 60 to $100 \mathrm{~min}$. An exponential decay function was fitted to the remaining bacterial counts over time to estimate an empirically derived detachment rate $\left(\delta_{\mathrm{e}}\right)$ (Kiørboe et al. 2002).

Bacterial motility and image analysis. Three Wadden Sea isolates (HP1, HP11, HP66) were selected for detailed motility observations. Starved and fed bacteria were resuspended in an observation chamber consisting of 2 rubber o-rings (1.9 $\mathrm{cm}$ in diameter) glued together and affixed to a microscope slide. The chamber was $0.5 \mathrm{~cm}$ deep and sealed with a cover slip. The bacteria were observed using dark-field microscopy and filmed at a 100× magnification. This method of motility measurements has an inherent limitation such that non-motile bacteria cannot be easily distinguished from inert objects. Thus, only clearly motile bacteria were considered in subsequent analyses. For each treatment, $20 \mathrm{~s}$ of footage were analyzed for motile bacteria. Bacterial swimming tracks were digitized using ImagePro 5 software. The digital field of view was approximately $900 \times 600 \mu \mathrm{m}$. Projected 2-dimensional swimming tracks (40 to 50) that were in focus were analyzed for run length at a 0.1 s resolution and turn angle at a 0.5 to $0.7 \mathrm{~s}$ resolution. Convective heating created a small net flow in the chambers, which was corrected for in the analysis using additional tracks of abiotic particles in the field of view. The average 3-dimensional speed of the bacterium was estimated as $(3 / 2)^{1 / 2}$ multiplied by the corrected 2-dimensional speed, and the empirically derived diffusivity $\left(D_{\mathrm{e}}\right)$ was calculated according to Kiørboe et al. (2002):

$$
D_{\mathrm{e}}=\frac{u^{2} \tau}{6(1-\alpha)}
$$

where $u$ is the swimming velocity; $\tau$ is the run length; and $\alpha$ is the mean cosine of the angles between 2 successive runs. Additionally, swimming speed data were used to generate frequency distributions for both starved and fed treatments. Bacterial diffusivity, swimming speed and turn angles between treatments were tested for significant differences using Student's $t$-test. When data were not normally distributed, the MannWhitney $U$-test was used.

\section{RESULTS}

\section{Colonization}

All 6 strains of bacteria accumulated on agar beads over time in a fashion similar to that previ- ously described (Fig. 1) (Kiørboe et al. 2002). For each strain tested, initial and final ambient cell counts did not differ (Student's $t$-test, $\mathrm{p}>0.147$ ) and no dividing cells were observed on the agar beads under the microscope, indicating no significant cell growth during the incubation. Bacterial abundances on the agar beads were normalized to ambient bacterial concentration to correct for slight differences in ambient bacterial concentrations within treatments (Kiørboe et al. 2002). For each of the 6 strains, there was a significant increase in normalized abundance over time, and the fed treatment was significantly different from the starved treatment (2-way ANOVA on rank-transformed data; $p<0.001)$. Differences in normalized bacterial abundances on beads between starved and fed treatments were further tested using Mann-Whitney $U$-test for each time point. For all strains tested, fed bacteria accumulated to higher overall abundances than starved bacteria. Normalized abundances of fed HP5 and YR3 bacteria were always significantly higher on beads than their starved bacterial abundances for all sampled time points (HP5, p $<0.031$; YR3, p $<0.011$ ). Three strains tested (HP1, HP11, YR7) had fed and starved normalized abundances that were not significantly different at time 0 but diverged thereafter (HP1, p = 0.163; HP11, p = 0.186; YR7, p = 0.104). Fed bacterial abundances for those 3 strains were significantly higher from 5 to $150 \mathrm{~min}$ (HP1, p < 0.003; HP11, p < 0.026; YR7, p < 0.005). Normalized abundances for fed and starved HP66 were not statistically different for time $0(\mathrm{p}=0.427)$ or $5 \mathrm{~min}(\mathrm{p}=$ 0.385). However, fed HP66 accumulated to significantly higher levels after 10 to $150 \mathrm{~min}$ ( $\mathrm{p}<0.031$ ).

The model of Kiørboe et al. (2002) (Eq. 1) fit significantly to the data $(\mathrm{p}<0.011)$. The colonization coefficient $R_{\mathrm{m}}$ averaged $( \pm 1 \mathrm{SD}) 9.1 \times 10^{-3}\left( \pm 3.8 \times 10^{-3}\right)$ for starved bacteria and $24.9 \times 10^{-3}\left( \pm 13.7 \times 10^{-3}\right)$ for fed bacteria (Table 1). $R_{\mathrm{m}}$ for fed Wadden Sea isolates was 2.4 to 3.7 times greater than their starved counterparts. Fed York River isolates had an $R_{\mathrm{m}} 1.5$ to 2 times higher than their starved counterparts.

\section{Detachment}

Bacterial detachment from the agar beads followed an exponential decay function (Fig. 2). Curve fits were significant ( $\mathrm{p}<0.05$ ) except for HP5 and HP66 fed, and YR3 starved, where scatter was larger. Linear regressions of natural-log-transformed data were compared for slopes using Student's $t$-test, and the slopes were not different between starved and fed treatments $(\mathrm{p}>$ $0.05)$. Calculated $\delta_{\mathrm{e}}$ were on the order of $10^{-4}$ to $10^{-3} \mathrm{~s}^{-1}$ (Table 2). 

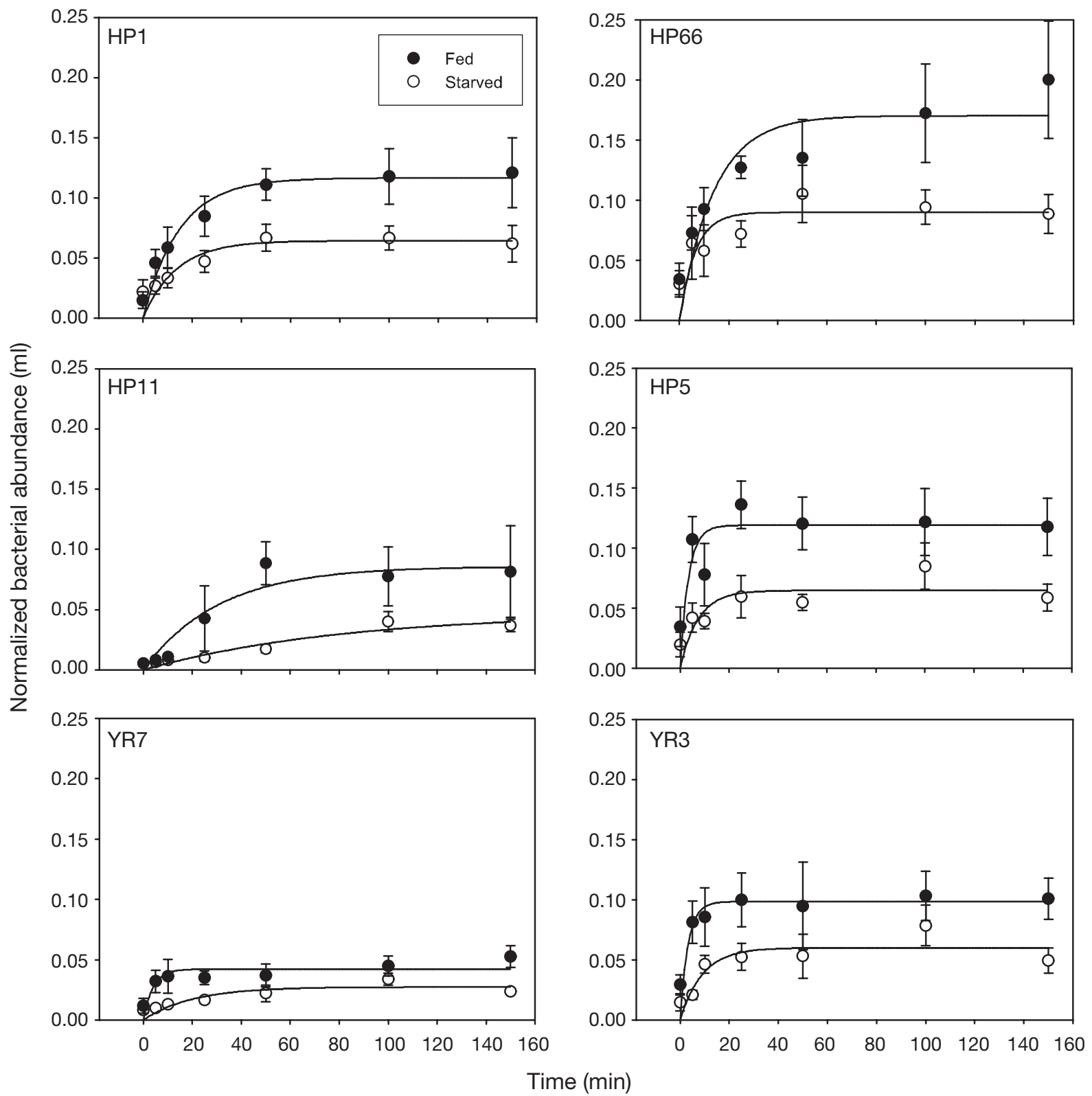

Fig. 1. Colonization of model aggregates (agar beads) by fed and starved bacteria. Abundances of attached bacteria per aggregate are normalized to ambient bacteria counts. Error bars indicate \pm SD of 10 counts. Plotted lines represent fits of colonization model (Kiørboe et al. 2002) to the data. 'HP' bacteria were originally isolated from the Wadden Sea, Germany; 'YR' strains were isolated from the York River, Virginia, USA

\section{Motility and image analyses}

Motility data were collected for HP1, HP11, and HP66. Average $D_{\mathrm{e}}$ calculated from motility data ranged from $0.20 \times 10^{-5}$ to $4.23 \times 10^{-5} \mathrm{~cm}^{2} \mathrm{~s}^{-1}$ (Table 3 ). Average $D_{\text {e }}$ of fed bacteria was 6.9 to 7.7 times higher than that of starved bacteria for HP1 ( $t$-test; $\mathrm{p}<0.0001$ ) and HP11 ( $t$-test; $\mathrm{p}=0.008$ ). $D_{\mathrm{e}}$ of starved and fed HP66 were not significantly different (Mann-Whitney, $\mathrm{p}=$ 0.61). Swimming speeds varied by 2 - to 3 -fold even within treatments (Table 3 ). The frequency distribu- tions of swimming speeds between starved and fed treatments overlapped to different extents among the tested strains (Fig. 3). About $70 \%$ of starved HP1 had average speeds between 10 and $20 \mu \mathrm{m} \mathrm{s}{ }^{-1}$, where nearly $88 \%$ of fed HP1 had average speeds between 30 and $60 \mu \mathrm{m} \mathrm{s} \mathrm{s}^{-1}$. The average speed for starved HP1 (18.4 $\mathrm{m} \mathrm{s} \mathrm{s}^{-1}$ ) was significantly lower than fed HP1 (37.8 $\mu \mathrm{m} \mathrm{s}^{-1}$; Mann-Whitney, $\left.\mathrm{p}<0.0001\right)$. For HP11, $86 \%$ starved and $22 \%$ fed bacteria had average speeds between 20 and $40 \mu \mathrm{m} \mathrm{s} \mathrm{s}^{-1}$. The average speed for starved HP11 (22.6 $\mathrm{m} \mathrm{s} \mathrm{s}^{-1}$ ) was significantly lower than 
Table 1. Colonization coefficient $\left(R_{\mathrm{m}}\right)$ based on diffusivity $\left(D_{\mathrm{m}}\right)$ and detachment rate $\left(\delta_{\mathrm{m}}\right)$ derived from model fits to the colonization experiment data using Eq. (1). 'HP' bacteria were originally isolated from the Wadden Sea, Germany; 'YR' strains were isolated from the York River, Virginia, USA

\begin{tabular}{|lcc|}
\hline Strain & Starved & Fed \\
\hline HP1 & 0.0089 & 0.0289 \\
HP5 & 0.0104 & 0.0248 \\
HP11 & 0.0058 & 0.0214 \\
HP66 & 0.0152 & 0.0482 \\
YR3 & 0.0100 & 0.0192 \\
YR7 & 0.0045 & 0.0067 \\
\hline
\end{tabular}

for fed HP11 (45.6 $\mu \mathrm{m} \mathrm{s}^{-1}$; $t$-test, $\left.\mathrm{p}<0.0001\right)$. Turn angles were not statistically different between treatments for either strain (Mann-Whitney, $\mathrm{p}=0.21$ and 0.78 for HP1 and HP11, respectively).

Approximately $98 \%$ of the starved HP66 and $91 \%$ of the fed HP66 swam at speeds from 20 to $75 \mu \mathrm{m} \mathrm{s}^{-1}$. A small percentage of fed HP66 had speeds reaching $88.6 \mu \mathrm{m} \mathrm{s}^{-1}$. Despite the overlap, average speeds for starved HP66 were lower than for fed HP66 ( $t$-test, p < 0.007). The average turn angle was significantly higher for starved versus fed treatments (MannWhitney, $\mathrm{p}=0.007$ ), such that HP66 had an average $\alpha$ of 0.82 in the starved treatment and 0.73 in the fed

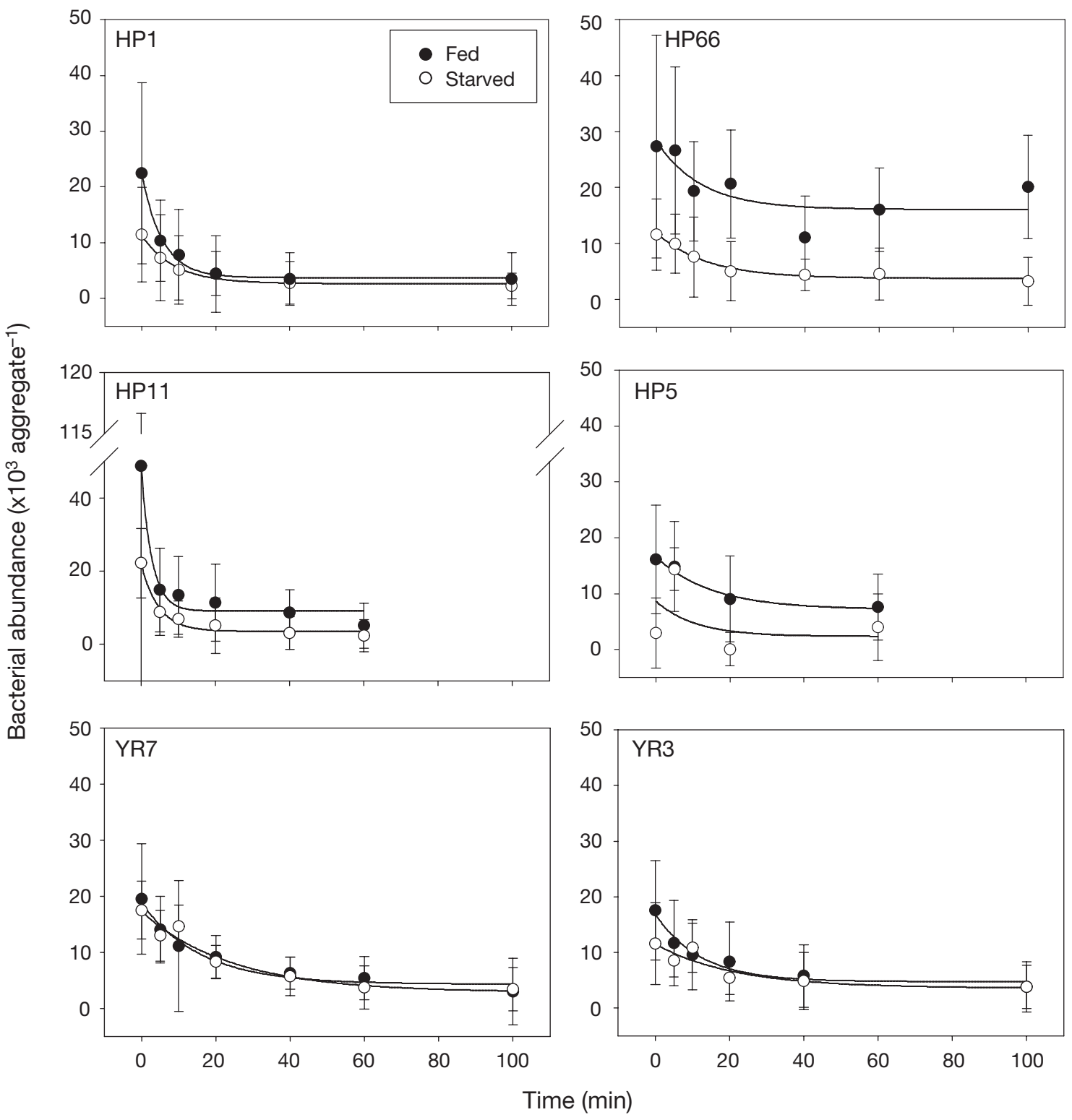

Fig. 2. Detachment of fed and starved bacteria from model aggregates (agar beads). Error bars indicate \pm SD from 10 bacterial counts. Plotted lines represent fits of exponential decay functions to the data. Note the scale differs on the $y$-axis for HP11 
Table 2. Empirically derived detachment rate $\left(\delta_{\mathrm{e} i} \times 10^{-3} \mathrm{~s}^{-1}\right.$, mean $\pm \mathrm{SD}$ ) based on detachment experiments

\begin{tabular}{|lcc|}
\hline Strain & Starved & Fed \\
\hline HP1 & $1.88 \pm 0.4$ & $3.01 \pm 0.4$ \\
HP5 & $1.39 \pm 0.5$ & $1.10 \pm 0.6$ \\
HP11 & $3.55 \pm 0.7$ & $5.81 \pm 1.8$ \\
HP66 & $1.23 \pm 0.2$ & $1.38 \pm 1.2$ \\
YR3 & $0.79 \pm 0.6$ & $1.38 \pm 0.4$ \\
YR7 & $0.69 \pm 0.2$ & $1.05 \pm 0.2$ \\
\hline
\end{tabular}
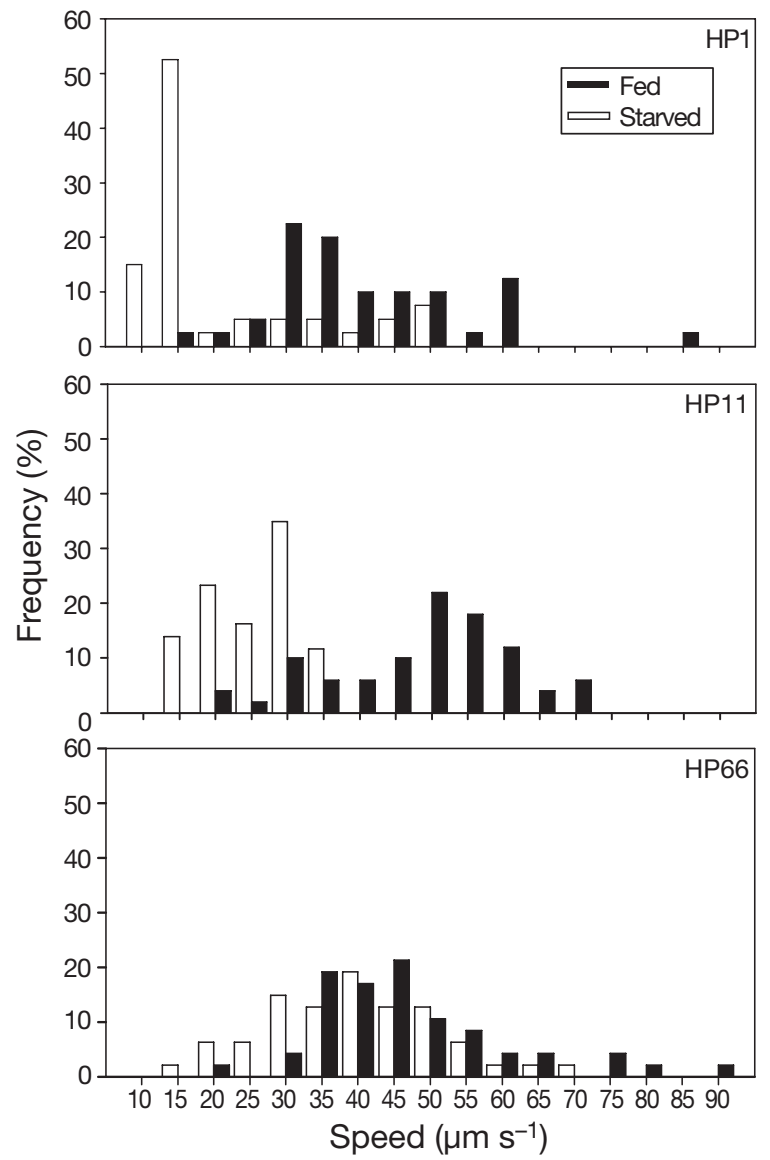

Fig. 3. Frequency distributions of swimming speeds for fed and starved bacteria treatment. Overall $D_{\mathrm{e}}$ for starved and fed HP66 bacteria were not statistically different (Mann-Whitney, $\mathrm{p}=$ 0.62).

The empirically derived $D_{\mathrm{e}}$ and $\delta_{\mathrm{e}}$ were used to calculate $R_{\mathrm{e}}$. $R_{\mathrm{e}}$ values for starved and fed HP1 were $1 \times$ $10^{-3}$ and $5.1 \times 10^{-3}$, respectively. HP11 had an $R_{\mathrm{e}}$ of $1.7 \times 10^{-3}$ in the starved treatment and a higher $R_{\mathrm{e}}$ in the fed treatment $\left(7.3 \times 10^{-3}\right) . R_{\mathrm{e}}$ for HP66 showed the reverse trend, where starved bacteria had a higher $R_{\mathrm{e}}$ $\left(31.3 \times 10^{-3}\right)$ than the fed bacteria $\left(17.4 \times 10^{-3}\right)$.

\section{DISCUSSION}

Previous experimental and modeling studies of aggregate-bacteria interactions have not adequately considered the effects of starvation on bacteria, and are largely biased toward actively growing bacteria in non-limiting nutrient environments. However, studies using metabolic dye or micro-autoradiography typically reveal a high percentage of inactive bacteria across different aquatic systems (Smith \& del Giorgio 2003), and a recent study showed that marine snow bacteria can up- and down-regulate their enzyme activity while on and off aggregate surface in as little as $2 \mathrm{~h}$ (Grossart et al. 2007). Other studies have also shown clear effects of starvation on bacterial physiology and behavior (Kjelleberg \& Hermansson 1984, Wrangstadh et al. 1986, 1990), and that these effects could occur within the time required for a bacterium to encounter an aggregate in the upper ocean (Malmcrona-Friberg et al. 1990, Wrangstadh et al. 1990, Wei \& Bauer 1998). Much of the world's surface ocean is characterized by low nutrients and primary production, and aggregate distribution is highly patchy, such that starvation (short to long term) is an important consideration for understanding aggregate-bacteria interactions.

In the present study, starvation effects were evident within $24 \mathrm{~h}$, resulting in 40 to $70 \%$ reduction in $R_{\mathrm{m}}$, such that starved bacteria colonized the model aggregates at a much lower rate and accumulated to signifi-

Table 3. Motility parameters for starved and fed bacteria based on image analysis of swimming tracks. Values are average for 40 to 50 tracks $(\mathrm{n})$ per treatment. Diffusivities $\left(D_{\mathrm{e}}\right)$ are calculated using Eq. (2). $\alpha$ : cosine of turn angles of the swimming tracks

\begin{tabular}{|c|c|c|c|c|c|c|c|c|}
\hline Strain & Treatment & $\begin{array}{c}D_{\mathrm{e}} \\
\left(\times 10^{-5} \mathrm{~cm}^{2} \mathrm{~s}^{-1}\right)\end{array}$ & $\overline{\text { Mean } \pm \mathrm{SD}}$ & $\begin{array}{l}\text { nming sp } \\
\text { Median }\end{array}$ & $\begin{array}{c}\left.\mu \mathrm{m} \mathrm{s}^{-1}\right) \\
\text { Min. }\end{array}$ & Max. & $\alpha$ & $\mathrm{n}$ \\
\hline HP1 & Starved & 0.20 & $18.37 \pm 12.3$ & 11.50 & 8.02 & 48.00 & 0.79 & 40 \\
\hline HP1 & Fed & 1.54 & $37.83 \pm 13.6$ & 34.53 & 14.81 & 83.16 & 0.67 & 40 \\
\hline HP11 & Starved & 0.61 & $22.56 \pm 5.9$ & 22.58 & 12.24 & 31.93 & 0.84 & 43 \\
\hline HP11 & Fed & 4.23 & $45.55 \pm 12.6$ & 46.88 & 15.93 & 68.35 & 0.83 & 50 \\
\hline HP66 & Starved & 3.85 & $37.49 \pm 12.2$ & 37.42 & 9.27 & 66.14 & 0.82 & 47 \\
\hline HP66 & Fed & 2.35 & $44.52 \pm 13.8$ & 42.31 & 19.69 & 88.55 & 0.73 & 47 \\
\hline
\end{tabular}


cantly lower steady-state abundance on the model aggregates. Differences in the colonization behaviors between fed and starved bacteria were corroborated by independently observed bacterial motility, in which starvation resulted in nearly $50 \%$ reduction in average swimming speeds for 2 of the 3 strains. Empirically derived $D_{\mathrm{e}}$ and $\delta_{\mathrm{e}}$ were similar to those reported in other studies (Kiørboe et al. 2002, 2003, Grossart et al. 2006). Starvation had no effect on $\delta_{\mathrm{e}}$. This implies that while starvation may affect motility, it has little effect on the cell surface structures of these bacteria for adhesion to surfaces (cf. van Schie \& Fletcher 1999, Castellanos et al. 2000). Another possible explanation is that the starved bacteria were able to quickly derive some nutrition from the agar beads after colonization and attained a physiological condition similar to that of the fed bacteria during the detachment measurements.

Despite the limited effect of starvation on detachment, detachment is still an important factor in understanding microbial dynamics on marine snow. Although aggregates represent a source of nutrients for marine snow bacteria, they are also risky environments where bacteria could be exposed to high grazing pressure (Caron 1987, Kiørboe et al. 2003). In a recent mesocosm study, Tang et al. (2006) showed that strong grazing pressure from flagellated protozoa could limit the residence time of bacteria on aggregate surfaces (calculated as the steady-state abundance of bacteria divided by the colonization rate) to $21 \mathrm{~min}$ or less. The duration of attachment to aggregates may be a trade-off between the risk of predation and the need for nutrients.

The motility response of HP1, HP11 and HP66 to starvation varied even within the populations. Heterogeneous physiological responses to starvation have been observed by others. For example, Wei \& Bauer (1998) reported that after $8 \mathrm{~h}$ of starvation, while the majority of the bacterium Rhizobium meliloti had shortened or lost flagella, some maintained at least 2 full-length flagella. Similarly, Stretton et al. (1997) showed that after $24 \mathrm{~h}$ of starvation, the cell morphology of Vibrio sp. S14 varied from coccoid to rod-shaped cells with or without flagella. This heterogeneity in flagellation and cell morphology may also account for the variations in motility in our experiments.

Despite the variation, starved HP1 and HP11 typically moved slower, which would lead to lower encounter rate with aggregates, consistent with the observed lower colonization rates in our experiments. Analyses of the swimming tracks also showed that differences in diffusivities between fed and starved treatments were mainly driven by differences in swimming speeds and not turn angles.

Not all of the strains were affected by starvation in the same way. For HP66, colonization data show that fed and starved treatments were not significantly different for the first several minutes, consistent with the observations that fed and starved HP66 had similar swimming speeds and turn angles. Nevertheless, fed HP66 did accumulate to a significantly higher abundance than starved HP66 on the model aggregates. This observation could not be explained by a difference in their $\delta_{\mathrm{e}}$, but rather may be a result of their different chemotactic response to the model aggregates or ability to attach upon encounter. These factors could not be adequately accounted for by the colonization model or motility observations.

In this study, we define a coefficient $R(=D / \delta)$ to characterize the overall colonization process. Comparisons between starved and fed treatments were similar for both $R_{\mathrm{m}}$ (model) and $R_{\mathrm{e}}$ (empirical) such that the $R$ values were consistently higher for fed bacteria (except for HP66). However, the calculated $R_{\mathrm{e}}$ tend to be smaller than $R_{\mathrm{m}}$ within treatments. A number of factors may contribute to a discrepancy between $R_{\mathrm{e}}$ and $R_{\mathrm{m}}$. (1) Empirically derived $D_{\mathrm{e}}$ were based on observed motility of the bacteria in suspension, but not all motile bacteria that encounter an aggregate will necessarily attach, in which case $D_{\mathrm{e}}$ would overestimate the true diffusivity. (2) In contrast, $D_{\mathrm{e}}$ assumes that the presence of aggregates would not affect the motility pattern of the bacteria. Many bacteria, however, exhibit a chemotactic response to aggregates (Kiørboe et al. 2002, Grossart et al. 2007). Although we used plain agar beads to minimize this effect, it is still possible that the bacteria were chemically attracted to the agar beads, resulting in a higher diffusivity than $D_{\mathrm{e}}$. (3) Finally, attached marine snow bacteria may produce signaling molecules (Gram et al. 2002) that facilitate or inhibit the subsequent arrival of other bacteria (Grossart et al. 2003). These cell-cell interactions could not be revealed by motility observations.

Microbial dynamics on marine snow are complex and involve processes leading to encounter and the development of microbial populations on the aggregates. Marine snow bacteria play a critical role in solubilizing marine aggregates and mediating organic matter fluxes between particulate and dissolved phases (Smith et al. 1992). Understanding how bacteria influence microscale processes in biogeochemical cycling requires determining not only the mechanisms by which bacteria colonize aggregates, but also potential shifts in behavior and responses to starvation, which is a likely condition given rapidly changing nutrient conditions and the patchy distribution of aggregates in the open ocean. Different patterns in colonization resulting from starvation may lead to variations in microbial activity associated with particles and fluxes between particulate and dissolved phases; 
this is a potential avenue for further study. Changes in physiology due to starvation need to be incorporated into models examining microscale processes occurring on marine snow aggregates, as these processes have important implications for the fluxes of organic matter on a larger scale.

Acknowledgements. This study was supported by a grant from the US National Science Foundation (OCE-0352125) awarded to K.W. T. and H.W.D. We thank H.-P. Grossart for providing the marine snow bacteria. We gratefully acknowledge T. Kiørboe for suggestions on modeling, R. Diaz for suggestions on statistics, K. Chaterji for technical assistance, and A. B. Bochdansky, E. A. Canuel, H. W. Ducklow, and D. K. Steinberg for reviewing earlier drafts of the manuscript. Additionally, we thank 2 anonymous reviewers and the editors for their constructive comments. This is contribution no. 2847 of the Virginia Institute of Marine Science.

\section{LITERATURE CITED}

Alldredge A (1979) The chemical composition of macroscopic aggregates in two neretic seas. Limnol Oceanogr 24: 855-866

Alldredge A, Gottschalk CC (1990) The relative contribution of marine snow of different origins to biological processes in coastal waters. Cont Shelf Res 10:41-58

Artolozaga I, Santamaria E, Lopez A, Ayo B, Iriberri J (1997) Succession of bacterivorous protists on laboratory-made marine snow. J Plankton Res 19:1429-1440

Benitez-Nelson C, Buesseler KO, Karl DM, Andrews J (2001) A time-series study of particulate matter export in the North Pacific Subtropical Gyre based on ${ }^{234} \mathrm{Th}:{ }^{238} \mathrm{U}$ disequilibrium. Deep-Sea Res I 48:2595-2611

Berg HC (1983) Random walks in biology. Princeton University Press, Princeton, NJ

Caron DA (1987) Grazing of attached bacteria by heterotrophic microflagellates. Microb Ecol 13:203-218

Caron DA (1993) Enrichment, isolation, and culture of freeliving heterotrophic flagellates. In: Kemp PF, Sherr BF, Sherr E, Cole JJ (eds) Handbook of methods in aquatic microbial ecology. Lewis Publishers, Boca Raton, FL

Caron DA, Davis PG, Madin LP, Sieburth JM (1982) Heterotrophic bacteria and bacterivorous protozoa in oceanic macroaggregates. Science 218:795-797

Castellanos T, Ascencio F, Bashan Y (2000) Starvationinduced changes in the cell surface of Azospirillum lipoferum. FEMS Microbiol Ecol 33:1-9

Cho B, Azam F (1988) Major role of bateria in biogeochemical fluxes in the ocean's interior. Nature 332:441-443

Cronenberg C (1994) Biochemical engineering on a microscale: biofilms investigated with needle-type glucose sensors. PhD dissertation, University of Amsterdam

DeLong EF, Franks D, Alldredge A (1993) Phylogenetic diversity of aggregate-attached vs. free-living marine bacterial assemblages. Limnol Oceanogr 38:924-934

Dilling L, Wilson J, Steinberg D, Alldredge A (1998) Feeding by the euphausiid Euphausia pacifica and the copepod Calanus pacificus on marine snow. Mar Ecol Prog Ser 170: 189-201

Fenchel T (2001) Eppur si muove: many water column bacteria are motile. Aquat Microb Ecol 24:197-201

Gram L, Grossart H-P, Schlingloff A, Kiørboe T (2002) Possi- ble quorum sensing in marine snow bacteria: production of acylated homoserine lactones by Roseobacter strains isolated from marine snow. Appl Environ Microbiol 68: 4111-4116

Grossart HP, Kiørboe T, Tang K, Ploug H (2003) Bacterial colonization of particles: growth and interactions. Appl Environ Microbiol 69:3500-3509

Grossart HP, Schlingloff A, Bernhard M, Simon M, Brinkhoff $T$ (2004) Antagonistic activity of bacteria isolated from organic aggregates of the German Wadden Sea. FEMS Microbiol Ecol 47:387-396

Grossart HP, Kiørboe T, Tang KW, Allgaier M, Yam EM, Ploug $H$ (2006) Interactions between marine snow and heterotrophic bacteria: aggregate formation and microbial dynamics. Aquat Microb Ecol 42:19-26

Grossart HP, Tang KW, Kiørboe, Ploug H (2007) Comparison of cell-specific activity between free-living and attached bacteria using isolates and natural assemblages. FEMS Microbiol Lett 266:194-200

Kiørboe T, Grossart HP, Ploug H, Tang K (2002) Mechanisms and rates of bacterial colonization of sinking aggregates. Appl Environ Microbiol 68:3996-4006

Kiørboe T, Tang K, Grossart HP, Ploug H (2003) Dynamics of microbial communities on marine snow aggregates: colonization, growth, detachment, and grazing mortality of attached bacteria. Appl Environ Microbiol 69: 3036-3047

Kirchman D (1993) Particulate detritus and bacteria in marine environments. In: Ford TF (ed) Aquatic microbiology: an ecological approach. Blackwell Scientific, Boston, MA, p 321-341

Kjelleberg S, Hermansson M (1984) Starvation-induced effects on bacterial surface characteristics. Appl Environ Microbiol 48:497-503

Malmcrona-Friberg K, Goodman AE, Kjelleberg S (1990) Chemotactic responses to marine Vibrio sp. Strain S14 (CCUG 15956) to low-molecular weight substances under starvation and recovery conditions. Appl Environ Microbiol 56:3699-3704

Mitchell JG (1991) The influence of cell size on marine bacterial motility and energetics. Microb Ecol 22:227-238

Mitchell JG, Kogure K (2006) Bacterial motility: links to the environment and a driving force for microbial physics. FEMS Microbiol Ecol 55:3-16

Pilskaln C, Villareal T, Dennett M, Darkangelo-Wood C, Meadows G (2005) High concentrations of marine snow and diatom algal mats in the North Pacific Subtropical Gyre: implications for carbon and nitrogen cycles in the oligotrophic ocean. Deep-Sea Res I 52:2315-2332

Silver M, Shanks AL, Trent JD (1978) Marine snow: microplankton habit and source of small-scale patchiness in pelagic populations. Science 201:371-373

Simon M, Grossart HP, Schweitzer B, Ploug H (2002) Microbial ecology of organic aggregates in aquatic ecosystems. Aquat Microb Ecol 28:175-211

Smith DC, Simon M, Alldredge A, Azam F (1992) Intense hydrolytic enzyme activity on marine aggregates and implications for rapid particle dissolution. Nature 359: 139-141

Smith EM, del Giorgio PA (2003) Low fractions of active bacteria in natural aquatic communities? Aquat Microb Ecol 31:203-208

Stretton S, Danon SJ, Kjelleberg S, Goodman AE (1997) Changes in cell morphology and motility in the marine Vibrio sp. strain S14 during conditions of starvation and recovery. FEMS Microbiol Lett 146:23-29

Tang KW, Grossart HP, Yam EM, Jackson G, Ducklow H, 
Kiorboe T (2006) Mesocosm study of particle dynamics and control of particle-associated bacteria by flagellate grazing. Mar Ecol Prog Ser 325:15-27

Thar R, Kuhl M (2003) Bacteria are not too small for spatial sensing of chemical gradients: an experimental evidence. Proc Natl Acad Sci USA 100:5748-5753

van Schie PM, Fletcher M (1999) Adhesion of biodegradative anaerobic bacteria to solid surfaces. Appl Environ Microbiol 65:5082-5088

Wei X, Bauer W (1998) Starvation-induced changes in motil-

Editorial responsibility: Josep Gasol,

Barcelona, Spain ity, chemotaxis, and flagellation of Rhizobium meliloti. Appl Environ Microbiol 64:1708-1714

Wrangstadh M, Conway PL, Kjelleberg S (1986) The production and release of an extracellular polysaccharide during starvation of a marine Pseudomonas sp. and the effect thereof on adhesion. Arch Microbiol 145:220-227

Wrangstadh M, Szewzyk U, Ostling J, Kjelleberg S (1990) Starvation-specific formation of peripheral exopolysaccharide by a marine Pseudomonas sp, Strain S9. Appl Environ Microbiol 56:2065-2072

Submitted: January 5, 2007; Accepted: June 21, 2007 Proofs received from author(s): July 16, 2007 